\title{
Treatment of nonseptic bursitis with endoscopic surgery
}

\author{
Non-Septik bursitlerin endoskopik cerrahi ile tedavisi
}

Azad Yıldırım ${ }^{1}$, Ahmet Kapukaya² ${ }^{2}$ Yılmaz Mertsoy ${ }^{1}$, Şehmus Yiğit ${ }^{3}$, Mehmet Akif Çaçan²

\section{ABSTRACT}

Objective: The aim of this study was to show that endoscopic surgery is a simple and acceptable method for various problems associated with wounds, range of motion and that such surgery ensures an early return to work after treatment of nonresponding nonseptic bursitis.

Methods: Thirty-two patients with nonseptic bursitis caused by repeated minor trauma that did not respond to medical treatment from 2008 to 2012 were included in this study. Radiographic [anteroposterior and lateral], ultrasound, macro and microscopic analyses of drainage liquid and aerobic and anaerobic cultures were obtained from the patients for the diagnosis.

Results: The mean age was 40.8 years. Fifteen patients had prepatellar bursitis, 13 had olecranon bursitis and 4 had ankle bursitis. Two patients had a history of falling on their knee. The other patients had a history of repetitive stimulation. The mean follow up period was 2.6 years [range. 2-5 years] and no medical complications occurred after the endoscopic surgery; such as scarring, loss of sensation and infection. One recurrence in response to medical treatment was observed.

Conclusion: Endoscopic bursectomy is a short and acceptable procedure with excellent results in terms of returning to work early and minimal wound related problems. J Clin Exp Invest 2015; 6 (3): 220-223

Key worlds: Endoscopy, bursitis, treatment

\section{INTRODUCTION}

A synovial bursa is a gap that reduces friction between tissues. Approximately 150 bursae have been identified in the human body. Disease, infection, and inflammation most commonly develop in the olecranon bursa, in the lateral malleolar bursa and over the prepatellar bursa. Etiological factors, such as repeated excess friction, falling, or direct

\section{ÖZET}

Amaç: Amacımız, nonseptik bursitlerde endoskopik cerrahinin yara problemleri, hareket açıklıkları ve işe erken dönüş açısından çok önemli faydalar sağladığını gösteren kabul edilebilir bir işlem olduğunu göstermektir.

Yöntemler: Bu çalışmaya 2008-2012 yılları arasında medikal tedaviye yanıt vermemiş tekrarlayan minör travmalarla oluşmuş nonseptik bursitisli hastalar alındı. Tanı için tüm hastalarda; AP ve yan grafiler, ultrasound, sıvının mikro ve makroskopik analizleri ve aerobik ve anaerobik kültürler çalışıldı.

Bulgular: Yaş ortalamaları 40,8 yıl ve takip süresi 2,6[25] yıl olan ikisi diz travması ve diğerleri repetitif minör travmalarla oluşan 15 prepatellar 13 olekranon ve 4 ayak bileği bursitinde; endoskopik cerrahi sonrası yara skarı, duyu kaybı ve enfeksiyon gibi komplikasyonlar olmadı. Medikal tedaviye yanıt veren 1 adet nüks görüldü.

Sonuç: Endoskopik bursektomi kısa ameliyat ve işe dönme süresi, minimal yara problemleri ve mükemmel sonuçlar nedeniyle güvenilir ve uygulanabilir bir işlemdir.

Anahtar kelimeler: Bursit, endoskopi, tedavi

and continuous pressure, may cause treatment resistant nonseptic bursitis. These cases of bursitis are chronic in approximately $5 \%$ of patients. Staphylococcus aureus is often a factor in prepatellar bursa infections [1].

Conservative treatment for chronic nonseptic bursitis involves drainage, nonsteroidal anti-inflammatory drugs, local steroid, cold pack application, and bandaging. Cases of bursitis that do not re-

\footnotetext{
${ }^{1}$ Gazi Yaşargil Training and Research Hospital Orthopaedics\&Travmatology Diyarbakır, Turkey

${ }^{2}$ Dicle Univercity Medical Faculty Orthopaedics\&Travmatology. Diyarbakır, Turkey

${ }^{3}$ Private Sultan Hospital. Diyarbakır, Turkey
}

Correspondence: Azad Yıldırım,

Gazi Yaşargil Training and Research Hospital Orthopaedics\&Travmatology, Diyarbakır, Turkey Email:yildirimazad@gmail.com

Received: 21.06.2015, Accepted: 10.09.2015

Copyright @ JCEI / Journal of Clinical and Experimental Investigations 2015, All rights reserved 
spond to conservative treatment are treated surgically. Some authors have reported the treatment of chronic nonresponsive bursitis using open surgery. Others have treated such cases with endoscopy and reported quite satisfactory results $[2,3]$.

The purpose of this study was to evaluate the outcome of treatment of chronic bursitis using endoscopy in patients who were nonresponsive to conservative treatment.

\section{METHODS}

Ethic committee approval were obtained, and all the participants signed informed consent form for the current study. Thirty two patients with bursitis who were admitted to our clinic and did not respond to medical treatment from 2008 to 2012 were included. Two dimensional D-joint graphics [anteroposterior and lateral], ultrasound, and macro and microscopic analyses of drainage liquid were obtained from the patients for the diagnosis. No patient had evidence of a systemic disease, such as rheumatoid arthritis, gout arthritis, infection or diabetes mellitus. A 3 week minimum of medical treatment was applied in our clinic for all of these patients.

The treatment comprised nonsteroidal anti inflammatory drugs, compressive bandaging, cold pack application, aspiration, and intraarticular steroid injections. All patients followed their control times. In terms of the patients clinical and laboratory history, two patients had prepatellar bursitis due to falling, and the remaining patients had chronic nonseptic bursitis due to repetitive movements. Preoperative and postoperative records were obtained. No aerobic or anaerobic bacteria proliferated in any of the samples taken at surgery. Patients with olecranon and ankle bursitis underwent operations in the lateral position, and those with prepatellar bursitis underwent operations in the supine position under local anesthesia. No tourniquets were applied to any patient. Sterile fluid samples were taken after draping and sent to the laboratory. The local anesthetic agent was administered with adrenaline into and around the bursae. Two portals were opened routinely from the distal and proximal ends at the junction of the skin and bursae (Figure 1). A third portal was opened if needed. After local anesthesia, the bursae were entered with a trocar, inflated with fluid, and viewed endoscopically (Figure 2,3,4). The operation was then carried out with a radiofrequency device, a shaver, and punches. After all inflamed and villous structures (Figure 5) had been cleaned with a shaver, the walls of the cyst on both the subcutaneous and deep sides were removed with a punch.

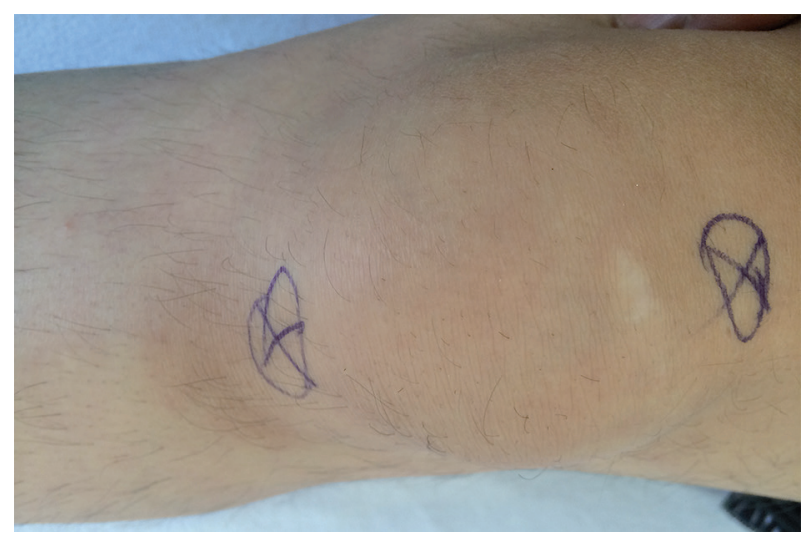

Figure 1. View of arthroscopic portals in the prepatellar bursitis

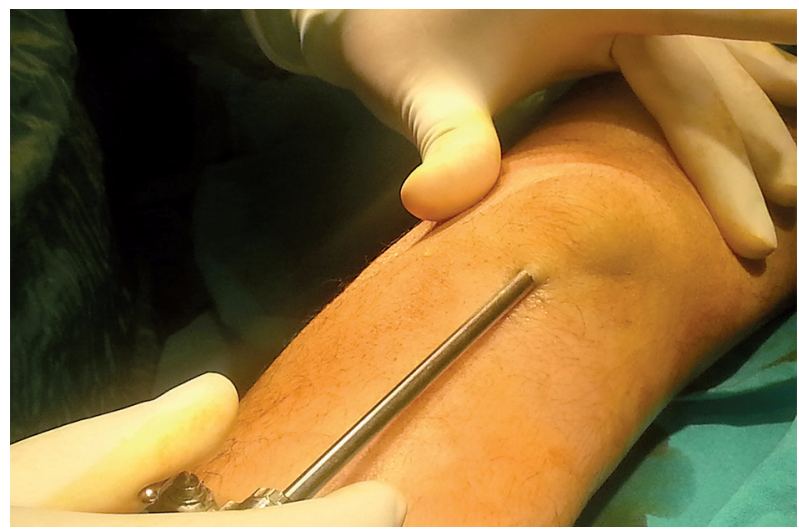

Figure 2. In the operation, when the bursae were entered with a trocar

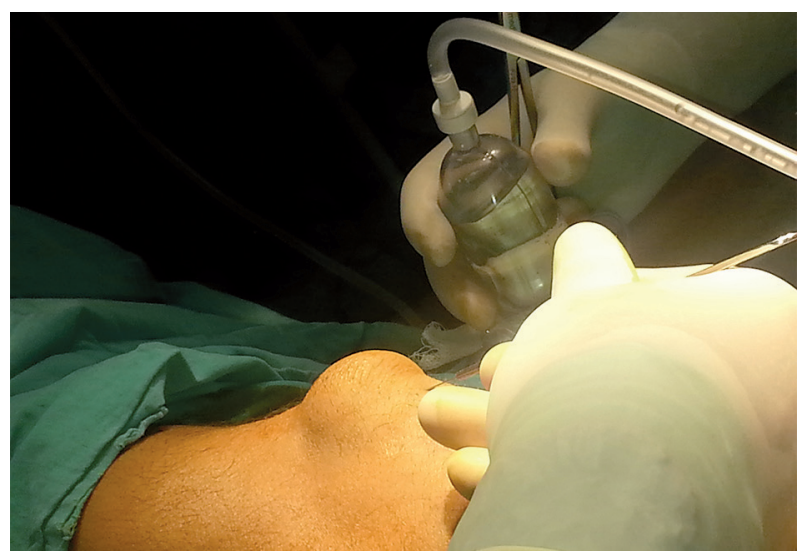

Figure 3. When bursae İnflated with fluid 


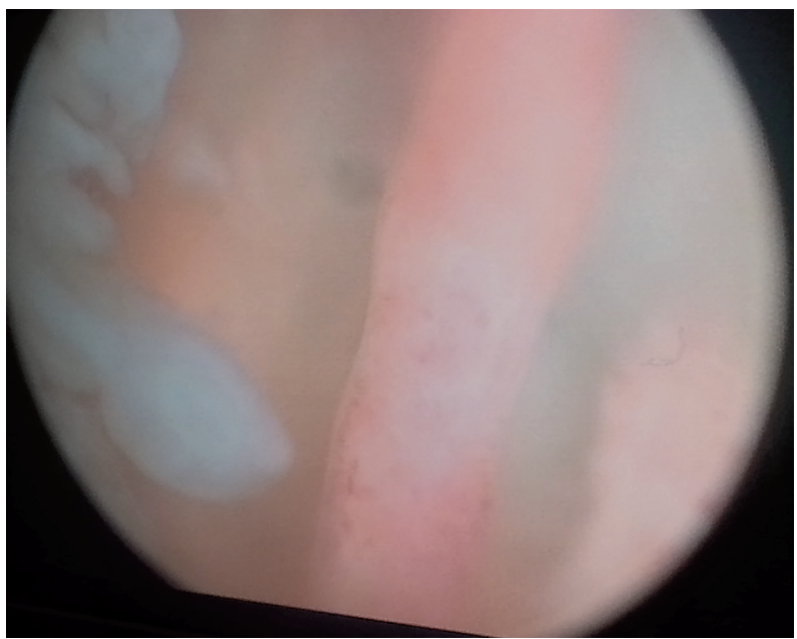

Figure 4. Villous structures and bursae wall viewed endoscopically

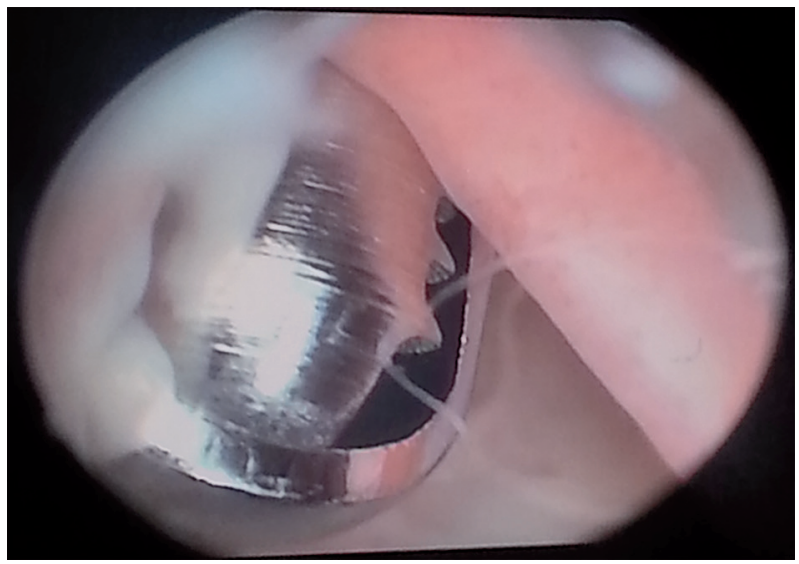

Figure 5. Villous structures and the walls of the cyst had been cleaned with shaver and punches

The cyst wall was removed nearly completely if the wall of the bursa was thickened due to chronic inflammation. However, if the lesion was acute and effusing, it was not removed completely because the cyst wall was not thick enough. However, enough was removed to resolve the patient's symptoms. We observed no difference between removing the wall on the subcutaneous side and removing the wall on the deep side. No triceps or patellar tendons were penetrated in any patients. Drains were not installed in any cases. The portal distal to the swelling was not sutured to allow drainage.

Elastic bandaging was applied postoperatively to avoid interference with circulation. Patients were discharged the same day. Cefazolin was used for prophylaxis. During hospitalization, the limb was el- evated for circulation and cold packs were applied. The patients were seen on days 3,10 , and 15 after surgery. After the first 3 days of elevation of the limb to promote circulation, cold pack applications were recommended at the follow up. Sutures were removed on day 15 postoperatively. The patients were invited for follow up during months $1,3,6$, and 12 postoperatively. Pain, swelling and range of motion of the ankles, elbows and knees were checked and recorded at the follow ups. Significant repeated swelling together with tenderness and pain were considered to indicate recurrence. Although patients were requested to undergo ultrasonography at the follow ups, radiographs were obtained to identify loose bone fragments.

\section{RESULTS}

Of the 32 patients, 23 were male and 9 were female. The mean age of the patients was 40.8 years [range. 27-65 years]. Fifteen patients had prepatellar bursitis, 13 had olecranon bursitis and 4 had ankle bursitis. An ipsilateral infection was present in all patients; 21 were on the right and 11 were on the left. Tests and examinations revealed no systemic diseases such as acute supurative infection, gout arthritis, rheumatoid arthritis or alcoholism. No patients had a history of steroid use or major trauma. Two patients had a history of falling on their knee. The other patients had a history of repetitive stimulation. Most aspirates were hemorrhagic or serohemorrhagic depending on the duration of inflammation, but a serous aspirate was obtained in one patient in his first month. Fifteen patients were housewives, eight were farmers, five were students, three were teachers and one was a doctor. The patients were followed for 2.6 years [range. 2-5 years]. A recurrence in response to medical treatment was seen in one patient. Complications such as hypertrophic scarring, loss of sensation and infection were not seen in any of the patients.

\section{DISCUSSION}

Bursitis may develop due to nonspecific or specific infections, arthritis and minor and major trauma $[1,4-7]$. Bursitis is treated conservatively with drainage, compressive bandages, cold pack applications and nonsteroidal anti inflammatory drugs [8] which take 2 to 3 weeks to have an effect. Surgery is considered in cases of bursitis unresponsive to this treatment. 
Open surgery is conventionally carried out; however, wound complications are a problem after surgery [1,2,9-14]; including late wound healing, local tenderness, hypertrophic scar tissue formation and loss of sensation [15]. Endoscopy is another surgical method; however, Witonski [16] reported that cosmetic and economic benefits are associated with endoscopic resection of prepatellar bursitis. According to Kerr [3], endoscopic bursectomy largely prevents wound problems. However, Kerr treated the majority of their patients under general anesthesia by hospitalizing them. In contrast, Huang and Yeh [17] treated their patients as outpatients under local anesthesia and reported successful results. We treated our patients as outpatients with local anesthesia as well, and we did not apply a tourniquet. The mean duration of the operation was 20 minute and the mean hospital stay was 2 to 4 hours. Only one patient developed recurrence in response to our medical treatment. Cicatrices, keloids or loss of sensation was not seen in any of our patients. Complications such as wound infections, joint motion, returning to work late and local loss of sensation are rarely seen after endoscopic procedures [18]. In experienced hands; endoscopy is a highly safe, effective and inexpensive surgical treatment for all types of bursitis with promising results.

In conclusion, endoscopy should be used routinely for treatment of bursitis and should be considered the primary surgical treatment option in all cases of bursitis unresponsive to medical treatment.

\section{REFERENCES}

1. Crenshaw AH. Campbells's operative orthopaedics. St Louis: Mosby; 1992.

2. Ogilvie Harris DJ, Gilbart M. Endoscopic bursal resection: the olecranon bursa and prepatellar bursa. Arthroscopy 2000;16:249-253.

3. Kerr DR. Prepatellar and olecranon arthroscopic bursectomy. Clin Sports Med. 1993;12:137-142.

4. Donahue F, Turkel D, Mnaymneh W, Ghandur Mnaymneh L. Hemorrhagic prepatellar bursitis. Skeletal Radiol 1996;25:298-301.
5. Garcia Porrua C, Gonzalez Gay MA, Ibanez D, Garcia Pais MJ. The clinical spectrum of severe septic bursitis in northwestern Spain: a 10 year study. J Rheumatol 1999;26:663-667.

6. Gomez Rodriguez N, Mendez Garcia MJ, Ferreiro Seoane JL, Ibanez Ruan J, Penelas-Cortes Bellas Y. [Infectious bursitis: study of 40 cases in the prepatellar and olecranon regions]. Enferm Infecc Microbiol Clín 1997; 15:237-242.

7. Papadakis KA, Vartivarian SE, Vassilaki ME, Anaissie EJ. Septic prepatellar bursitis caused by Stenotrophomonas (Xanthomonas) maltophilia. Clin Infect Dis 1996;22:388-389.

8. McAfee JH, Smith DL. Olecranon and prepatellar bursitis. Diagnosis and treatment. West J Med 1988;149:607-610.

9. Quayle JB, Robinson MP. A useful procedures in the treatment of chronic olecranon bursitis. Injury. 1978;9:299-302.

10. Quayle JB, Robinson MP. An operation for chronic prepatellar bursitis. J Bone Joint Surg (Br)1976;58:504506.

11. Nussbaumer $P$, Candrian C, Hollinger A. [Endoscopic bursa shaving in acute bursitis]. Swiss Surg 2001;7:121-125.

12. Steinacker T, Verdonck A. [Endoscopic therapy of prepatellar bursitis]. Sportverletz Sportschaden1998;12:162-164.

13. Stell IM. Management of acute bursitis: outcome study of a structured approach. J R Soc Med 1999;92:516521.

14. Freys SM. [Olecranon and prepatellar bursitis]. Langenbecks Arch Chir Suppl Kongressbd1997;114:493-496.

15. Pien FD, Ching D, Kim E. Septic bursitis: experience in a community practice. Orthopaedics 1991;14:981984.

16. Witonski D. [Arthroscopic resection of bursitis changes in the prepatellar bursae-preliminary report]. Chir Narzadov Ruchu Ortopedia Polska 1997;62:63-65.

17. Huang YC, Yeh WL. Endoscopic treatment of prepatellar bursitis. Int Orthop 2011;35:355-358.

18. Kaalund S, Breddam M, Kristensen G. Endoscopic resection of the septic prepatellar bursa. Arthroscopy 1998;14:757-758. 